CHAPTER 12:

\title{
Inequality in Citizenship Competences. Citizenship Education and Policy in the Netherlands
}

\author{
Anne Bert Dijkstra, Geert ten Dam, and Anke Munniksma ${ }^{1}$
}

\begin{abstract}
The Dutch school system is characterized by early educational tracking and high school autonomy. This chapter focuses on how this is related to citizenship competences among students. Results of IEA's International Civic and Citizenship Education Study (ICCS) 2016 study indicate that whereas by itself citizenship competences of students in the Netherlands seem reasonable, they lag behind those of their peers in comparable countries. Furthermore, relatively large differences in citizenship competences between students with different social backgrounds and between educational tracks are documented. These findings are discussed, with a critical reflection on how characteristics of the Dutch school system may have contributed to this, and suggestions to improve citizenship education in the Netherlands are made.
\end{abstract}

\section{Introduction}

The International Association for the Evaluation of Educational Achievement (IEA) International Civic and Citizenship Education Study (ICCS) 2016 conducted in the Netherlands provides a comprehensive overview of citizenship education and its outcomes. At first glance, the results seem satisfactory. The majority of Dutch students support democratic notions of citizenship; on average, they trust the institutions of the democratic constitutional state. If we compare Dutch results with those obtained in other countries, however, they appear less positive. Dutch schools pay less attention to citizenship education and students have fewer citizenship competences (i.e., knowledge, skills, and attitudes) than their peers in comparable countries. They are also less socially and politically involved and are less positive about values such as equal rights for different ethnic groups. Moreover, there are relatively large differences between Dutch students from different socioeconomic backgrounds, and substantial differences in citizenship competences between students in the various educational tracks (Schulz et al. 2018).

This chapter's central theme is the inequality in citizenship competences among students. The Netherlands provides an interesting case to study this issue, given the allocation of students to different educational tracks at age 12 as well as the high level of school autonomy in citizenship education.

We start with the policy context. What citizenship task has the government assigned to the schools and what latitude and resources do schools have to carry it out? Next, we will describe citizenship education in Dutch secondary schools and the citizenship competences of their students, mainly based on ICCS 2016 results. These results will then be compared to those of other countries and over time. Next, we will discuss the options available to the Dutch government to strengthen citizenship education, and conclude by sketching future scenarios for Dutch citizenship education policy to foster equality in citizenship competences among students, and future research.

1 Anne Bert Dijkstra and Geert ten Dam are Professors of Education and Anke Munniksma is Assistant Professor at the Department of Educational Sciences, University of Amsterdam. Together, they were program directors and project leader of the Dutch ICCS 2016 study.

Anne Bert Dijkstra, University of Amsterdam, Amsterdam, the Netherlands email: a.b.dijkstra@uva.nl

Geert ten Dam, University of Amsterdam, Amsterdam, the Netherlands

email: g.t.m.tendam@uva.nl

Anke Munniksma, University of Amsterdam, Amsterdam, the Netherlands

email: a.munniksma@uva.nl

(C) IEA International Association for the Evaluation of Educational Achievement 2021

B. Malak-Minkiewicz and J. Torney-Purta (eds.), Influences of the IEA Civic

and Citizenship Education Studies, https://doi.org/10.1007/978-3-030-71102-3_12 


\section{Citizenship Education in the Netherlands}

A strong and resilient democracy needs citizens who possess competences to participate in and contribute to society. Strengthening students' citizenship competences through education has recently become an important theme in politics, the public debate, and science (e.g., Haste 2010; Eurydice 2012, 2017). This arises from a desire to increase social cohesion (Oser and Veugelers 2008), that is, to harden the "social glue" that keeps society together and ensures that citizens feel committed to each other and are involved in society. In 2005/2006, the Dutch government laid down the promotion of citizenship in educational legislation and in the core objectives of primary and secondary education. The statutory citizenship obligation has been formulated in rather unspecified terms, and schools can determine its content, nature, and extent. However, it is specified that schools should promote "active citizenship and social integration." According to the Dutch Ministry of Education, "active citizenship" refers to "the willingness and ability to be part of a community and to make an active contribution to this community." "Social integration" refers to "participation of citizens in society (regardless of their ethnic or cultural background), in the form of civic participation, involvement in society and its institutions and familiarity with and commitment to manifestations of Dutch culture." ${ }^{2}$

The Netherlands was the last country in Europe to adopt citizenship education as a statutory obligation (Eurydice 2005). The reluctance of both the Dutch government and the school system to make citizenship part of the formal curriculum is no coincidence. A strong regulating factor, which affects the development of citizenship education and related policies, is the constitutional "freedom of education" (see Glenn and De Groof 2002; Dijkstra and Dronkers 2003). This principle allows organizations and groups to found schools and allows schools to design their curricula to shape teaching in line with a religious or philosophical orientation. The government makes no distinction between schools with regard to funding. School autonomy is deeply embedded in the history and culture of the Netherlands. The same article of the Constitution stipulates, however, that education is "of ongoing concern to the government." Thus, there is a balance between school autonomy and governmental controls aimed at achieving basic standards of schooling. Schools are free to design citizenship education as they see fit, as long as it respects the basic values of the democratic state and is based on an underlying vision aimed at active citizenship and social integration. How schools meet the citizenship obligation (e.g., teaching it as a separate subject, or through projects or embedded in other subjects), what content they teach and how much attention they pay to it is up to each school individually. ${ }^{3}$

It is therefore no surprise that the Dutch Inspectorate of Education (Inspectie van het Onderwijs 2016) warned that schools differ greatly with respect to the content, organization, and quality of citizenship teaching. Promotion of citizenship competences is found in some curriculum elements but it is often unclear how various activities are related. The connection between regular school subjects and citizenship-specific projects is often missing, as is a link with the school climate. Only a few schools have formulated learning objectives and most schools do not measure the effects of their citizenship teaching. However, because the statutory obligation to invest in citizenship education has been formulated in very general terms, without defining minimum contents or results, the formal competence of the Inspectorate to impose procedures is limited (Dijkstra et al. 2014). It cannot criticize the content, methods or frequency of teaching citizenship, even if these are very minimal. Only if schools violate the basic values of the democratic constitutional state can they be said to fall short of the statutory obligation. The result of the interplay between limited central steering and school autonomy is the deeply engrained variety in citizenship teaching practices across schools.

2 Active Citizenship and Social Integration Act, December 9, 2005, Dutch Ministry of Education and Science.

3 In addition to the statutory citizenship obligation, all senior students in secondary education (from age 15) are taught civic studies (maatschappijleer) as a separate subject. 


\section{Equal Opportunities and Citizenship Outcomes}

In addition, the Dutch school system is characterized by early educational tracking. After the final year of primary school, a selection process determines what secondary school type the student will attend: pre-vocational education ( $v m b o$ ), or one of the levels of general secondary education (havo or vwo) that prepare for higher education. The goal of early tracking is to suit instruction to the students' ability levels. However, this characteristic of the Dutch education system leads to students being assigned to a specific school type too early in their school career, and limits access to higher education (cf. OECD 2016). This reduces educational opportunities, especially for students from disadvantaged groups, and increases existing differences in cognitive performance.

Although the effects of early tracking on general academic achievement have been researched extensively, its effects on civic outcomes have not been studied. Do the negative effects of tracking also apply to citizenship competences? It could be that the effects are even more negative because of the relative homogeneous grouping of students within the tracks, in terms of social backgrounds. By this grouping, interaction with diverse individuals, an essential component of citizenship in a plural and multicultural society, is limited. The ICCS study conducted in the Netherlands illuminates the relation between tracking and citizenship outcomes, indicating that tracking may promote inequality in civic outcomes.

\section{Citizenship Competences and Citizenship Education in the Netherlands}

In this section, we focus on the most recent results of the ICCS 2016 study from different angles (Munniksma et al. 2017). First, we will present a general and descriptive picture of citizenship knowledge, attitudes, skills, and behaviours of the 14-year-old students involved. Next, to put this into perspective, we will compare the results with those from other countries with a focus on Belgium (Flanders) and the Scandinavian countries (Denmark, Finland, Norway, and Sweden). These countries are comparable to the Netherlands on the Human Development Index (HDI) of the United Nations Development Programme. Thereafter, we will look at different periods, by comparing the citizenship competences from 2016 to those of seven years earlier (ICCS 2009). Next, we will look at differences between schools and between students, including a focus on students' background characteristics and their academic track. Finally, we will examine these findings in the light of recent educational policies in the Netherlands.

\section{Citizenship Competences of Dutch Secondary School Students}

ICCS 2016 shows that most Dutch students in the second year of secondary school support democratic principles. In general, they trust the institutions of the democratic constitutional state. Most students feel that respecting differences of opinion is the most important aspect of good citizenship, and most are in favour of equal rights for men and women and, to a lesser extent, for ethnic minorities. They have limited confidence in their own citizenship competences (such as their ability to follow a debate or defend a point of view). To keep up-to-date with social and political issues, most students watch television (63\% at least once a week). Newspapers and the internet are used much less for this purpose (18\% and $10 \%$ respectively). In addition, $71 \%$ of students intend to vote when eligible. Their civic knowledge-about the ways in which a democratic society "works," the underlying principles and their application-is middling.

If we compare the Dutch ICCS 2016 findings to those of Flanders, Denmark, Finland, Norway, and Sweden, the most important conclusion is that Dutch students clearly have less citizenship knowledge than students in these other countries. The group of students with high scores is relatively small in the Netherlands, while students with low scores are relatively numerous.

The results of Dutch secondary school students also lag behind those of their peers in these comparable countries in other respects. This includes the importance students attach to conventional aspects of citizenship (e.g., voting in elections, learning the history of one's country) 
and to aspects of social commitment (e.g., participating in peaceful protests and activities to help people in the local community). Generally, their trust in political parties and the national parliament is relatively low. Furthermore, Dutch students are comparatively less inclined to grant women the same rights as men. By comparison, support for equal rights for all ethnic groups in society is also less strong among students in the Netherlands. Moreover, Dutch students lag behind their peers in comparable countries with respect to social and political participation, both currently and in their expectations about future participation. In line with these findings, Dutch students are (with students in Finland and Latvia) among the students who feel less confident about their own citizenship competences (e.g., being able to follow a TV-debate or defend a point of view).

\section{Inequalities}

To shed light on differences in Dutch schools, we compared students with different background characteristics. The ICCS findings show that boys and girls do not differ much with respect to citizenship competences. Girls have slightly more citizenship knowledge and more strongly support equal rights for men and women and equal rights for ethnic groups in society. They also report more civic participation (e.g., voluntary work), than boys. There are no gender differences with respect to trust in societal institutions, confidence about one's citizenship competences, and expected voting behaviour. These gender differences are generally comparable to the differences found in other countries.

There are also differences between students with and without a migration background. The former are more often in favour of equal rights for all ethnic groups. These groups do not differ, however, with respect to their opinions about equal rights for men and women. Students with a migration background have less trust in societal institutions and think it is less likely that they will vote in the future. In addition, they have less citizenship knowledge than non-migrants. The two groups do not differ in civic participation. These results are in line with those in the comparison countries, with the differences in citizenship knowledge between migrant and nonmigrant students being relatively small in the Netherlands.

Differences between students with lower and higher educated parents are much more substantial. This is particularly true for citizenship knowledge and for supporting equal rights for men and women and ethnic groups, where students with lower educated parents have substantially lower scores. In Finland and Norway, this difference in citizenship knowledge is smaller than in the Netherlands, while it is equally large in Flanders, Denmark, and Sweden. We also see that children of less educated parents in the Netherlands report less trust in societal institutions and appear less inclined to vote. The same pattern occurs in the comparison countries. By contrast, the difference between children of lower and higher educated parents with respect to confidence in their own citizenship competences is small, in both the Netherlands and the comparison countries. Civic participation does not differ between children of lower and higher educated parents in the Netherlands, Sweden, and Finland, while it does in Flanders, Denmark, and Norway.

In sum, there are considerable differences in citizenship competences between students from different social backgrounds. These differences are more or less similar to those in 2009 (Maslowski et al. 2012) and remained virtually unchanged in comparing students with and without a migration background. As in 2009, students from families with a higher level of education have more citizenship knowledge and more strongly support equal rights for groups in society. What is striking is that in 2016 girls have more citizenship knowledge than boys (whereas there was no gender difference in 2009, and boys had more citizenship knowledge in 1971; Maslowski et al. 2012; Torney et al. 1975). 


\section{Differences Between Educational Tracks}

Since Dutch schools' practice early selection of students into different educational tracks, comparing these tracks is warranted. Earlier we explained that the Dutch education system is characterized by strong external differentiation through separate secondary school types: vmbo (prevocational education), and havo and vwo/gymnasium. This is reflected in the citizenship results. Students in the latter two school types have more citizenship knowledge and think it is more likely that they will vote later in life. They have more trust in societal institutions and are more in favour of equal rights for all ethnic groups. In contrast, there are only small differences between school types with respect to students' confidence in their own citizenship competences and civic participation. However, the differences in citizenship knowledge between school types are larger in 2016 than in 2009 (see Maslowski et al. 2012; Munniksma et al. 2017). The knowledge level of vmbo students in 2016 was about the same as in 2009, while students in the higher school types scored higher than in 2009.

Reasons for this relatively large inequality in the Netherlands could be the ways in which citizenship education is organized in the various school types or the student grouping into tracks. Other quantitative research shows that Dutch schools that prepare their students for higher education are convinced that critical citizenship and personal development are important, while vocational schools are more focused on adjustment-oriented citizenship and socially acceptable behaviour (Ten Dam and Volman 2003; Leenders et al. 2008). With respect to student grouping, longitudinal research in Germany and the United Kingdom shows that placement in different educational tracks is related to differences in citizenship outcomes between students in these tracks (Eckstein et al. 2012; Janmaat et al. 2014). The Dutch system's early tracking of students appears likely to contribute to the relatively large differences in citizenship competences found in the Netherlands. However, data to draw far-reaching conclusions about these differences and the underlying mechanisms are currently lacking.

\section{Citizenship Teaching}

What does the ICCS 2016 study tell us about the state of citizenship teaching in the Netherlands? The ICCS 2016 findings show that, compared to schools in other countries, Dutch schools invest less in several aspects of citizenship education. Dutch students, unlike their peers in the comparison countries, feel that the classroom climate is not especially conducive to discussion. They also paint a more negative picture of the relationships between students and teachers than their foreign peers (although they have become slightly more positive since 2009). Furthermore, a relatively small percentage of Dutch students participate in citizenship activities at school (e.g., having a say in how the school is run or standing for or voting in elections for class representatives, the school parliament, or the student council). In the Netherlands, students also have fewer opportunities to participate in school affairs than their peers in the comparison countries.

We also see differences in citizenship education between educational tracks. In higher tracks, students participate more in democratic activities and feel that this is important. Students in higher tracks also report a more open classroom climate for discussion and more positive studentteacher relations. In contrast, lower track students indicate to have learned more about topics related to citizenship at school, than higher track students. The same impression emerges from the results of the ICCS 2016 surveys among school managers and teachers. A large majority of school managers state that students (like their parents and their teachers) have little or no say in school affairs. Compared to other countries, Dutch students also show less interest in such participation. Teachers make relatively little use of available teaching aids but mainly use textbooks and workbooks. Overall, they indicate that they feel less competent to teach topics related to citizenship than their peers in other countries. This is true for topics such as elections, the constitution, and international organizations but less so for critical thinking or responsible internet use. 
Overall, it is not surprising that the percentages of Dutch students who state that they have learned about various citizenship topics are lower than those in most comparison countries. It should be noted that most students only attend maatschappijleer (civic studies) ${ }^{4}$ classes after their second year of secondary school. However, also next to teaching civic knowledge in the formal curriculum, there appears to be less space to practice citizenship in Dutch schools than in other countries.

\section{Differences in Citizenship Knowledge Between and Within Schools}

The ICCS 2009 results showed that, on average, 28\% of the differences in student citizenship knowledge can be explained by school characteristics, while $72 \%$ can be attributed to individual student characteristics. To what extent are these results similar in the 2016 study?

The ICCS 2016 results show that the overall amount of variation in citizenship knowledge among students in the Netherlands is comparable to all ICCS countries. However, if we specifically take a look at the differences between schools versus the differences within schools, the Netherlands do stand out: of all ICCS countries, the percentage of the total variance (differences) between schools is the largest in the Netherlands (55\%). In the comparison countries this ranged from $40 \%$ in Belgium (Flanders) to $6 \%$ in Norway and Finland. Put more simply, there are more high scoring schools and more low scoring schools in the Netherlands than elsewhere.

Similar to the 2009 findings, it also appears that a large percentage (74\%) of the differences in citizenship knowledge between schools can be explained by the personal and social background characteristics of students enrolled in schools. Student characteristics such as socioeconomic status, the language spoken at home and the expectation that the student will go on to university are strongly related to the type of school attended by the student and also explains most of the differences in civic knowledge between schools. These characteristics explain the differences in civic knowledge within Dutch school to a far lesser degree. Furthermore, relatively little of the differences between schools can be explained by the extent of teaching about citizenship offered at school. In summary, results indicate that most of the differences between schools in students' citizenship knowledge can be attributed to differences in the backgrounds of the students who compose the school's student body.

\section{The Citizenship Education Debate: Autonomy and Accountability}

It is frequently observed that citizenship education in the Netherlands does not meet the expectations. As previously stated, the Dutch Inspectorate of Education has repeatedly reported that the development of citizenship education is stagnating (most recently, Inspectie van het Onderwijs 2016). The Inspectorate attributes this to the quality of the teaching. Other studies also show that there is little specific attention to what students should learn about citizenship and how this should be taught. This applies to both primary and secondary education (Maslowski et al. 2012). One problem affecting the quality of citizenship teaching is a lack of reliable information about the existing citizenship competences of students. This means that schools are unable to adapt their teaching to what their students need (Inspectie van het Onderwijs 2016). At the system level there is at best a limited understanding of what is needed. Although some national studies are available (e.g., Geijsel et al. 2012; Dijkstra et al. 2015; Geboers et al. 2015), relatively little is known about the characteristics of citizenship education and its outcomes. These are not new questions, as publications by educational researchers have shown (e.g., Bron and Thijs 2011; Veugelers 2007).

The results of international comparative research also shed light on the current situation. The ICCS studies give rise to various questions about the quality of Dutch citizenship education and

4 This course, maatschappijleer, is taught in all secondary schools by an accredited teacher for this subject, and covers topics related to civics. 
inform the public debate about whether citizenship education satisfies society's expectations, and where improvement is necessary and feasible. The ICCS 2009 and 2016 studies show that the citizenship competences of Dutch secondary school students are less developed than those of their peers in neighbouring countries, and there has hardly been any improvement (Kerr et al. 2010; Schulz et al. 2010; Maslowski et al. 2012; Munniksma et al. 2017). Moreover, the differences among Dutch students are relatively large. Nationally representative samples of schools such as those of IEA are essential to address questions related to within and between school variance associated with social background. The Netherlands will participate in the next ICCS cycle, in 2022, which will allow us to follow these developments over a longer period.

Meanwhile, the debate about the school's statutory obligation to teach citizenship continues. In the Netherlands, an important element is the issue of the so-far limited steering by the central government. Although the law stipulates that schools must pay attention to citizenship, they are free to choose the content, approach, and quantity. This freedom in education has led to great variation in the way in which citizenship is taught. It also allowed schools to teach in a way that is unfocused and ineffective and has led to stagnation in the development of citizenship education. Although the position of the Dutch government can partly be understood from its reluctance to prescribe particular values to be taught, the traditional importance attached to school autonomy plays an even greater role (Glenn and De Groof 2002; Dijkstra and Dronkers 2003). The result is a mix of factors-the statutory obligation which is defined in very general terms and the struggle of school managers and teachers to "give this theme flesh and bones." Until recently, the guiding principle of each school's autonomy limited many initiatives to develop citizenship education.

This situation makes empirical data on citizenship education and its outcomes especially important. The results of ICCS 2009 and ICCS 2016, which show that there has been little improvement since the schools were obliged to invest in citizenship education, play an important role in the Dutch debate. The disappointing citizenship outcomes combined with existing concerns about social cohesion and polarization in society have led to a debate about the need for strengthening citizenship education. The findings of the ICCS studies provide documentation of the relatively modest outcomes in comparison to those in neighbouring countries and the relatively large differences between schools and between academic and vocational tracks.

The Dutch Education Council, an influential and independent advisory body of the Dutch government and parliament, has also taken up the gauntlet. In 2012, the Council advised that the government tightens control in the area of citizenship teaching. The Council advised that all schools should be offered legal guidelines stating specific expectations concerned with teaching students about the democratic constitutional state and how they could function in a democratic society (Onderwijsraad 2012). The Inspectorate of Education also advocated that schools should be given more guidance and resources for school development (Inspectie van het Onderwijs 2016). Finally, citizenship has been given a prominent place in current curriculum innovation initiatives for primary and secondary education. How this will be realized and what effect this will have on the content and organization of teaching cannot be determined yet. After the parliamentary debate, which is still to occur, it will in all likelihood take several years before concrete initiatives will reach the schools.

Nevertheless, some-as yet cautious-government efforts to strengthen citizenship teaching have become manifest. One initiative was a "performance agreement" to improve educational quality negotiated with the sector organization for secondary education (2014). This has the goal of increasing the average citizenship knowledge of Dutch secondary school students by 2020. Given the, although small, rise in absolute scores on citizenship knowledge, and despite growing inequalities, the results were evaluated positively by the Ministry of Education, Culture and Science (2017). As mentioned before, the ICCS citizenship knowledge measurement clearly 
played a role in the arguments presented by the government. In 2017 and 2019, the government and the national sector organizations formulated two small scale projects involving 25 secondary schools to support strengthened citizenship teaching in secondary vocational and general education (with students between 12 and 18-years-old). The hesitant but growing attention paid to citizenship by the Dutch government has so far mainly taken the form of covenants with limited support. The question is whether this is enough to stop the observed stagnation in the development of citizenship education and its disappointing results.

Furthermore, as we have seen, there are large differences between and within Dutch schools with respect to the citizenship competences of their students. These differences are associated with socioeconomic backgrounds. An element of the state's responsibility for democracy is to show all young people not only that it is desirable to be a responsible citizen but also providing them with the necessary tools. This is not easy within the context of the Dutch education system, in which the government is obliged to respect widespread freedom in education. Schools are free to express their philosophical or religious identity and teach their students accordingly.

With respect to government action, Waslander et al. (2018) have developed a useful "steering trilogy" based on Foucault's governmentality concept. The authors state that to manage an educational theme (like citizenship education), three things are necessary: making the subject thinkable, calculable, and practicable.

With regard to the first factor, making the subject thinkable, a clear and common "language" is required. The more specifically the object of steering is described, the less latitude there is for personal interpretation. The current legislation obliging schools to teach citizenship is formulated in such general terms that it hardly provides any guidance. The same applies to the related core objectives. Qualitative research also shows that board members, school managers, and teachers often have different ideas about the substance of citizenship education-even when they are working at the same school (Waslander and Pater 2017). Research shows that schools, if they are to teach citizenship effectively, should explicitly formulate their citizenship goals, design a specific teaching program, and monitor the outcomes. In particular the differences between students in socioeconomic background should be taken into account. School can and should compensate for societal inequality. The problems associated with early tracking, however, cannot be solved by individual schools.

Once the aim of citizenship education has been made thinkable, it should be made calculableconceptualizing how schools should assess, address, and evaluate these requirements. The consequences of poor results for schools and students should also be made calculable. At present, what results are required is unclear because the legislation does not specify what schools need to attain or commit to. Failing results do not have ramifications, which means that citizenship education is often not given sufficient attention, time, and resources in Dutch schools. Hence, the government should substantially increase both the monitoring of citizenship education and the development of measurement instruments.

After citizenship education has been made thinkable and calculable, the last step in steering should be taken: making it practicable. A call was made for additional support (e.g., covering effective methods, teacher training programs, and instruments for measuring outcomes) around the time that the statutory citizenship teaching obligation was introduced in 2005; only limited resources, however, were provided, for example, in the form of basic subject planning models. 


\section{Summary, Conclusions, and Suggestions for Further Research}

The results of the Dutch ICCS study show that most young people support democratic values and that their citizenship competences can be considered to be "reasonable" on the whole. In absolute figures, the citizenship knowledge of secondary school students is slightly higher than it was in 2009. Nevertheless, when compared to other countries, this impression must be reassessed: citizenship outcomes are lower than in comparable countries; the differences between schools are relatively large and schools pay less attention to citizenship education. Moreover, there are relatively large differences between students of parents with different socioeconomic backgrounds and between students in vocational and general secondary school tracks. The differences in citizenship knowledge between the school tracks have even grown since 2009. These results add considerably to the knowledge about the quality of Dutch citizenship education. The Inspectorate of Education and the national government advisory body (the Education Council) have repeatedly argued that at both school and system level there is little understanding of students' civic outcomes. The ICCS studies are important in this respect.

Although there are reasons to improve citizenship education, we have shown how complicated that process is in the Dutch context. School autonomy as a dominant principle is illustrated, for example, by the government's reluctance to formulate the statutory citizenship obligation in specific terms, and limited ambition with respect to improving the outcomes. In addition, there is a need to support schools in their efforts to improve citizenship teaching. This has so far been implemented in a noncommittal fashion and has been based on the willingness of the sector organizations for primary and secondary education to take action. However, a revision of the statutory citizenship obligation, which will come into effect in 2021-2022, is being prepared. This might address one of the two main obstacles to the development of citizenship education (more clarity for schools on what is expected of them) but not the other (the lack of a supportive infrastructure for schools). Remarkably, the intended national curriculum revision, in which strengthening the societal task of schools is a major consideration, appears not to have had a stimulating effect. In keeping with the Dutch tradition, the education field, where the influence of both educational organizations and teachers is strong, has assumed an important role in this process. There are few safeguards for quality assurance or governmental steering in terms of content.

Further research, including international comparative studies such as ICCS, could make an important contribution to the future development of citizenship teaching and citizenship results. A positive factor is the decision of the Ministry of Education, Culture and Science to participate in the ICCS 2022 cycle and also to organize a supplementary national study (in 2020). This new information, to be based on ICCS instruments, will not only contribute to our knowledge of the current situation that can be used as policy inputs, but could also lead to a better understanding of the relation between characteristics of citizenship education and its outcomes. This could lead to better insight into "what works." It may be worthwhile to assign this a more prominent place in future ICCS research. For example, it may be valuable to investigate how specific characteristics of citizenship education are related to outcomes and to think about ways to give the ICCS design a closer fit with what nations need to know in order to develop effective national educational policies. Of course, international comparisons would be retained.

The question of what the school's contribution might be leads to an important issue. It seems evident that not only the schools, but parental resources, peers, and media have a substantial effect on citizenship competences. This should reduce expectations that only investments in education are required to promote citizenship competences. The fact that the influence of schools appears to have been modest shows that it is important to provide adequate steering about where schools can make their influence felt. In this respect, an important role is played 
by the potential ability of schools to compensate for background differences between students in relation to civic outcomes.

For both issues - what schools can do and how can this be steered-it is important to find out how citizenship results are influenced by the interplay of educational and societal factors. Relevant societal factors may be the socioeconomic and sociocultural opportunity structure (for example, social inequality), the extent to which different groups have trust in society and its institutions, and political representation for all groups. The international comparison inherent in ICCS offers excellent opportunities to gain a better understanding of these issues. This should include empirical research into the relationship between school practices and school policies aimed at developing citizenship teaching and their school-transcending determinants (e.g., steering at higher levels, statutory rules, and school supervision). It would also be valuable to thoroughly investigate how tracking (and the resulting increased segregation based on social backgrounds across schools) is related to citizenship education and its outcomes. This could contribute to a better understanding of which reforms are likely to succeed.

\section{The Need for Improvement}

The results of ICCS 2016 show better outcomes in many countries compared to 2009. This also applies to the Netherlands, where the citizenship knowledge of students increased and their attitudes in some respects, became slightly more positive. What has caused this improvement is unclear. The higher mean score on the knowledge test cannot hide the fact that a relatively large number of students have low scores. This also applies to the substantial differences between students attending schools at various levels. However, the fact that the results of Dutch students are lower than those of their peers in other countries not only means that the earlier gap still exists but that better results are possible. The previous edition of the ICCS study led to the same conclusion (Maslowski et al. 2012), as did the Education Council (2012) and the Inspectorate of Education (2016). The fact that the Netherlands has invested little in the quality of citizenship education suggests that there may be an as yet untapped potential for contributions from schools.

In sum, when we interpret the ICCS 2016 findings together with the available knowledge-base and the characteristics of the Dutch education system, we conclude that there is considerable room for improving citizenship education and civic outcomes. The fact that differences in citizenship outcomes between tracks and between schools are larger than in other countries raises serious questions and underscores the importance of specifying a minimum common core for citizenship education for all schools to reduce these differences. Ultimately, we want all students in the Netherlands to have the knowledge and competences required to take part in democratic society.

\section{References}

Bron, J., \& Thijs, A. (2011). Leaving it to the schools: citizenship, diversity and human rights education in the Netherlands. Educational Research, 53. https://doi.org/10.1080/00131881.2011.572361.

Dijkstra, A.B., \& Dronkers, J. (2003). Civil society as equilibrium. Governance and choice in education between private delivery and central regulation. In C.A. Torres, \& A. Antikainen (Eds.), The international handbook on the sociology of education (pp. 325-341). Lanham, MD: Rowman \& Littlefield.

Dijkstra, A.B., Geijsel, F., Ledoux, G., Van der Veen, I., \& Ten Dam, G. (2015). Effects of school quality, school citizenship policy, and student body composition on the acquisition of citizenship competences in the final year of primary education. School Effectiveness and School Improvement, 26, 1-30.

Dijkstra, A.B., El Khayati, N. \& Vosse, A. (2014). Evaluation of social outcomes in the Netherlands. In A.B. Dijkstra, \& P.I. De la Motte (Eds.), Social outcomes of education. The assessment of social outcomes and school improvement through school inspections (pp. 103-118). Amsterdam, the Netherlands: Amsterdam University Press.

Eckstein, K., Noack, P., \& Gniewosz, B. (2012). Attitudes toward political engagement and willingness to participate in politics. Trajectories throughout adolescence. Journal of Adolescence, 35, 485-495. 
Eurydice. (2005). Citizenship education at school in Europe. Survey. Brussel, Belgium: European Commission.

Eurydice. (2012). Citizenship education at school in Europe. Survey. Brussels, Belgium: European Commission.

Eurydice. (2017). Citizenship education at school in Europe - 2017. Luxembourg: European Commission.

Geboers, E., Geijsel, F., Admiraal, W., Jorgensen, T., \& Ten Dam, G. (2015). Citizenship development during adolescence. Journal of Adolescence, 45, 89-97.

Geijsel, F., Ledoux, G., Reumerman, R., \& Ten Dam, G. (2012). Citizenship in young people's daily lives. Differences in citizenship competences of adolescents in the Netherlands. Journal of Youth Studies, 15, 711-729.

Glenn, C.L., \& Groof, J. de (2002). Finding the right balance. Freedom, autonomy and accountability in education. Utrecht, the Netherlands: Lemma.

Haste, H. (2010). Citizenship education: A critical look at a contested field. In L. R. Sherrod, J. TorneyPurta \& C. A. Flanagan (Eds.), Handbook of research on civic engagement in youth (pp. 161-188). Hoboken, NJ: John Wiley \& Sons.

Inspectie van het Onderwijs. (2016). Burgerschap op school. Een beschrijving van burgerschapsonderwijs en de maatschappelijke stage [Citizenship at school. A description of citizenship education and the social internship]. Utrecht, the Netherlands: Inspectie van het Onderwijs.

Janmaat, J.G., Mostafa, T., \& Hoskins, B. (2014). Widening the participation gap: The effect of educational track on reported voting in England. Journal of Adolescence, 37, 473-482.

Kerr, D., Sturman, L., Schulz, W., \& Burge, B. (2010). ICCS 2009 European Report. Civic knowledge, attitudes, and engagement among lower-secondary students in 24 European countries. Amsterdam, the Netherlands: International Association for the Evaluation of Educational Achievement (IEA).

Leenders, H., Veugelers, W., \& De Kat, E. (2008). Teachers' views on citizenship education in secondary education in The Netherlands Journal. Cambridge Journal of Education, 38, 155-170.

Maslowski, R., Van der Werf, M.P.C., Oonk, G.H.G., Naayer, H.M., \& Isac, M.M. (2012). Burgerschapscompetenties van leerlingen in de onderbouw van het voortgezet onderwijs. Eindrapport van de International Civic and Citizenship Education Study (ICCS) in Nederland [Citizenship competences of pupils in the lower grades of secondary education. Final report of the International Civic and Citizenship Education Study (ICCS) in the Netherlands]. Groningen, the Netherlands: GION/Rijksuniversiteit Groningen.

Ministry of Education, Culture and Science [The Netherlands]. (2017). Dashbord Sector Agreement secondary education 2017. https://www.tweedekamer.nl/kamerstukken/brieven_regering/detail?id=2 017Z18877\&did=2017D38835

Munniksma, A., Dijkstra, A.B., Van der Veen, I., Ledoux, G., Van de Werfhorst, H., \& Ten Dam, G. (2017). Burgerschap in het voortgezet onderwijs. Nederland in vergelijkend perspectief [Citizenship in secondary education. The Netherlands in comparative perspective]. Amsterdam, the Netherlands: Amsterdam University Press.

Onderwijsraad. (2012). Verder met burgerschap in het onderwijs [Continuing citizenship in education]. Den Haag, the Netherlands: Onderwijsraad.

Organisation for Economic Co-operation and Development (OECD). (2016). Netherlands 2016: Foundations for the future, reviews of national policies for education. Paris, France: OECD Publishing.

Oser, F., \& Veugelers, W. (2008). Getting involved. Global citizenship development and sources of moral values. Rotterdam, the Netherlands: Sense Publishers.

Schulz, W., Ainley, J., Fraillon, J., Losito, B., Agrusti, G., \& Friedman, T. (2018). Becoming citizens in a changing world: IEA International Civic and Citizenship Education Study 2016 international report. Cham, Switzerland: Springer.

Schulz, W., Ainley, J., Fraillon, J., Kerr, D., \& Losito, B. (2010). ICCS 2009 international report: Civic knowledge, attitudes, and engagement among lower- secondary school students in 38 countries. Amsterdam, the Netherlands: International Association for the Evaluation of Educational Achievement (IEA).

Ten Dam, G., \& Volman, M. (2003). A life jacket or an art of living: Inequality in social competence education. Curriculum Inquiry, 33, 116-137.

Torney, J., Oppenheim, A.N., \& Farnen, R.F. (1975). Civic education in ten countries: An empirical study. New York, NY: Halsted Press. 
Veugelers, W. (2007). Creating critical-democratic citizenship education: empowering humanity and democracy in Dutch education. Compare: A Journal of Comparative and International Education, 37, 105-119.

Waslander, S., Hooge, E.H., Theisens, H.C., \& Pater, C.J. (2018). Steering dynamics in complex education systems: Why similar aims can have dramatically different results. Journal of Education Policy, 35(2). https:// doi.org/10.1080/02680939.2018.1502895

Waslander, S., \& Pater, C.J. (2017). Sturingsdynamiek in het voortgezet onderwijs [Steering dynamics in secondary education]. Tilburg, the Netherlands: TIAS School for Business and Society Tilburg University.

Open Access This chapter is licensed under the terms of the Creative Commons Attribution-NonCommercial 4.0 International License (http://creativecommons.org/licenses/by-nc/4.0/), which permits any noncommercial use, sharing, adaptation, distribution and reproduction in any medium or format, as long as you give appropriate credit to the original author(s) and the source, provide a link to the Creative Commons license and indicate if changes were made.

The images or other third party material in this chapter are included in the chapter's Creative Commons license, unless indicated otherwise in a credit line to the material. If material is not included in the chapter's Creative Commons license and your intended use is not permitted by statutory regulation or exceeds the permitted use, you will need to obtain permission directly from the copyright holder. 